\title{
Możliwość poboru opłaty miejscowej od żeglarzy zawijających do portów lub przystani znajdujących się na wodach śródlądowych ${ }^{1}$
}

\begin{abstract}
The possibility of collecting a local fee from sailors calling at ports or harbours located in inland waters: Imposing an obligation for a port or a harbour administrators to collect a local fee from crew members of inland ships (yachts), which are mooring there, is not sufficiently legally grounded in the Act on Local Taxes and Fees. Inland ports and harbours are not generally classified as hotel facilities, and thus do not fulfill the provisions of this Act with regard to the existence of conditions enabling individuals to stay for tourism, recreation or training purposes in a locality, where local payment was imposed.
\end{abstract}

Keywords: fee, tax, sailing

Słowa kluczowe: opłata, podatek, żeglarstwo

Doktor nauk prawnych, ekspert ds. finansów publicznych BAS jacek.kulicki@sejm.gov.pl • https://orcid.org/0000-0003-2631-6428

\section{Przedmiot opinii}

Przedmiotem opinii jest odpowiedź na następujące pytania:

1) czy porty mogą pobierać od żeglarzy na rzecz gmin opłatę klimatyczną? Na jakich zasadach?, czy można wprowadzić rozwiązania tożsame z hotelami (port jako miejsce gościny, nie jacht sam w sobie)?,

2) czy firma, która posiada kontrakt na sprzątanie np. linii brzegowej jeziora $\mathrm{z}$ daną gminą, na terenie której zlokalizowane jest miejsce nieformalnego postoju użytkowane przez żeglarzy, tzw. binduga (miejsce nad rzeką, kanałem, jeziorem), może pobierać opłatę miejscową (klimatyczną) na rzecz gminy?

1 Opinia prawna w sprawie możliwości poboru opłaty miejscowej od żeglarzy zawijajacych do portów lub przystani znajdujących się na wodach śródlądowych sporządzona 22 lutego 2019 r. na zlecenie posła Klubu Poselskiego Polskiego Stronnictwa Ludowego - Unii Europejskich Demokratów; BAS-WASiE 208/19. 
U podstaw przedstawionych pytań, znalazła się wątpliwość dotycząca tego, że: (o)płata miejscowa (tak zwany „podatek klimatyczny”) jest pobierana od każdej osoby za każda dobę w przypadku domków, apartamentów czy hoteli w miastach i gminach, które wprowadzity te opłatę. Opłata ta jednak nie jest pobierana od żeglarzy, którzy tak naprawdę znajduja się na "pływajacych domkach”, czyli jachtach (z możliwością noclegu codziennie w innym porcie, w innej gminie), a którzy jak wszyscy inni turyści, od których opłatę się pobiera produkują śmieci, ścieki, zużywaja prad, wodę itp.

\section{Stan prawny w zakresie objętym pytaniami}

W zakresie objętym pytaniami obowiązują:

- ustawa z 12 stycznia 1991 r. o podatkach i opłatach lokalnych, t.j. Dz.U. 2018, poz. 1445, ze zm.; dalej: u.p.lok.,

- ustawa z 29 sierpnia 1997 r. - Ordynacja podatkowa, t.j. Dz.U. 2018, poz. 800, ze zm.; dalej: o.p.,

- ustawa z ustawa z 13 września 1996 r. o utrzymaniu czystości i porządku w gminach, t.j. Dz.U. 2018, poz. 1454, ze zm.; dalej: u.porz.,

- 29 sierpnia 2003 r. o urzędowych nazwach miejscowości i obiektów fizjograficznych (Dz.U. nr 166, poz. 1612, ze zm.; dalej: u.u.nazw.,

- ustawa z 29 sierpnia 1997 r. o usługach hotelarskich oraz usługach pilotów wycieczek i przewodników turystycznych, t.j. Dz.U. 2017, poz. 1553, ze zm.; dalej: u.u.hot.,

- ustawa z 21 grudnia 2000 r. o żegludze śródlądowej, t.j. Dz.U. 2017, poz. 2128, ze zm.; dalej: u.ż.ś.,

- rozporządzenie Rady Ministrów z 18 grudnia 2007 r. w sprawie warunków, jakie powinna spełniać miejscowość, w której można pobierać opłatę miejscową, Dz.U. nr 249, poz. 1851; dalej: rozporządzenie Rady Ministrów z 18 grudnia 2007 r.

Pierwsza z przywołanych ustaw kształtuje obowiązek daninowy w zakresie opłaty miejscowej. Zgodnie z art. 17 ust. 1 u.p.lok. opłata miejscowa może być wprowadzona przez radę gminy. Pobierana jest ona od osób fizycznych - za każdą rozpoczętą dobę pobytu - przebywających dłużej niż dobę w celach turystycznych, wypoczynkowych lub szkoleniowych:

- w miejscowościach posiadających korzystne właściwości klimatyczne, walory krajobrazowe oraz warunki umożliwiające pobyt osób w celach turystycznych, wypoczynkowych lub szkoleniowych (pkt 1),

- w miejscowościach znajdujących się na obszarach, którym nadano status obszaru ochrony uzdrowiskowej na zasadach określonych w ustawie z 28 lipca 2005 r. o lecznictwie uzdrowiskowym, uzdrowiskach i obszarach ochrony 
uzdrowiskowej oraz o gminach uzdrowiskowych (t.j. Dz.U. 2017, poz. 1056, ze zm.).

Opłaty tej nie pobiera się:

- pod warunkiem wzajemności - od członków personelu przedstawicielstw dyplomatycznych i urzędów konsularnych oraz innych osób zrównanych z nimi na podstawie ustaw, umów lub zwyczajów międzynarodowych, jeżeli nie są obywatelami polskimi i nie mają miejsca pobytu stałego na terytorium Rzeczypospolitej Polskiej (art. 17 ust. 2 pkt 1 u.p.lok.),

- od osób przebywających w szpitalach (art. 17 ust. 2 pkt 2 u.p.lok.),

- od osób niewidomych i ich przewodników (art. 17 ust. 2 pkt 3 u.p.lok.),

- od podatników podatku od nieruchomości z tytułu posiadania domów letniskowych położonych w miejscowości, w której pobiera się opłatę miejscową albo uzdrowiskową (art. 17 ust. 2 pkt 4 u.p.lok.).

- od zorganizowanych grup dzieci i młodzieży szkolnej (art. 17 ust. 2 pkt 5 u.p.lok.),

- od osób, od których pobierana jest opłata uzdrowiskowa² (art. 17 ust. 2a u.p.lok.).

Minimalne warunki, jakie powinna spełniać miejscowość, w której można pobierać opłatę miejscową, określa w drodze rozporządzenia Rada Ministrów (art. 17 ust. 3 u.p.lok.), przy czym rozporządzenie to powinno uwzględniać zróżnicowanie warunków regionalnych i lokalnych oraz - zgodnie $\mathrm{z}$ art. 17 ust. 4 u.p.lok. - określać warunki klimatyczne, krajobrazowe i umożliwiające pobyt osób w celach turystycznych, wypoczynkowych lub szkoleniowych ${ }^{3}$.

W kompetencjach rady gminy leży:

- ustalenie miejscowości odpowiadających warunkom ustawowym, w których pobiera się opłatę miejscową (art. 17 ust. 5 u.p.lok.),

- określenie zasad ustalania i poboru oraz terminu płatności i wysokości stawek opłaty miejscowej, przy czym stawka opłaty miejscowej nie może być wyższa od 2,26 zł lub 3,20 zł za dzień pobytu ${ }^{4}$ (art. 19 pkt 1 lit. b i c u.p.lok.),

- zarządzenie poboru opłaty miejscowej w drodze inkasa oraz określenie inkasentów i wysokość wynagrodzenia za inkaso, a także wprowadzenie obowiązku prowadzenia przez inkasentów ewidencji osób obowiązanych do uiszczenia opłaty miejscowej oraz określenie szczegółowego zakresu danych

2 Opłata uzdrowiskowa pobierana jest od osób fizycznych przebywających dłużej niż dobę $\mathrm{w}$ celach zdrowotnych, turystycznych, wypoczynkowych lub szkoleniowych w miejscowościach znajdujących się na obszarach, którym nadano status uzdrowiska (art. 17 ust. 1a u.p.lok.).

3 W tym zakresie obowiązuje rozporządzenie Rady Ministrów z 18 grudnia 2007 r. w sprawie warunków, jakie powinna spełniać miejscowość, w której można pobierać opłatę miejscową.

4 Zob. obwieszczenie Ministra Finansów z 25 lipca 2018 r. w sprawie górnych granic stawek kwotowych podatków i opłat lokalnych na rok 2019, M.P. poz. 745. 
zawartych $\mathrm{w}$ tej ewidencji, przy uwzględnieniu konieczności zapewnienia prawidłowego poboru opłaty miejscowej (art. 19 pkt 2 u.p.lok.),

- wprowadzenie innych niż wymienione w ustawie zwolnień przedmiotowych od opłaty miejscowej (art. 19 pkt 3 u.p.lok.).

Druga z przywołanych ustaw (ordynacja podatkowa) definiuje pojęcie inkasenta oraz jego odpowiedzialność za pobrane i nieodprowadzone podatki i opłaty.

\section{Analiza stanu prawnego w zakresie objętym pytaniami}

\section{Ad pytanie 1}

Jak wynika z przedstawionego wyżej stanu prawnego, uprawnienie do wprowadzenia opłaty miejscowej ma obecnie (od 1 stycznia 2016 r. ${ }^{5}$ ) charakter fakultatywny i zostało przyznane radzie gminy. Wprowadzenie opłaty miejscowej możliwe jest jednak wyłącznie:

- w miejscowościach posiadających korzystne właściwości klimatyczne, walory krajobrazowe oraz warunki umożliwiające pobyt osób w celach turystycznych, wypoczynkowych lub szkoleniowych,

- w miejscowościach znajdujących się na obszarach, którym nadano status obszaru ochrony uzdrowiskowej na zasadach określonych w ustawie o lecznictwie uzdrowiskowym, uzdrowiskach i obszarach ochrony uzdrowiskowej oraz o gminach uzdrowiskowych.

Z treści art. 17 ust. 1 pkt 1 i 2 u.p.lok wynika a contrario, że opłata miejscowa nie może być wprowadzona na terenie całej gminy, ale wyłącznie w poszczególnych jej miejscowościach: bądź posiadających korzystne właściwości klimatyczne, walory krajobrazowe oraz warunki umożliwiające pobyt osób w celach turystycznych, wypoczynkowych lub szkoleniowych (pkt 1), bądź też znajdujących się na obszarach, którym nadano status obszaru ochrony uzdrowiskowej (pkt 2).

\section{- Pojęcie miejscowości}

Ustawa o podatkach i opłatach lokalnych nie definiuje pojęcia miejscowości, stąd zgodnie z ogólną zasadą interpretacyjną należy, przy definiowaniu tego pojęcia dla celów ustawy o podatkach lokalnych, uwzględnić legalną (normatywną) definicję tego określenia ${ }^{6}$, która zawarta jest w ustawie z 29 sierpnia 2003 r. o urzędowych nazwach miejscowości i obiektów fizjograficznych.

5 Zob. art. 9 pkt 11 lit. a tiret pierwsze ustawy z 25 czerwca 2015 r. o zmianie ustawy o samorządzie gminnym oraz niektórych innych ustaw, Dz.U. poz. 1045, ze zm.

6 Zob. m.in. wyrok WSA w Bydgoszczy z 27 kwietnia 2011 r., sygn. akt I SA/BD 76/11, LEX nr 787022. 
Zgodnie z art. 2 pkt 4 u.u.nazw. za miejscowość - dla celów tej ustawy - uznawana jest jednostka osadnicza lub inny obszar zabudowany odróżniające się od innych miejscowości odrębną nazwą, a przy jednakowej nazwie - odmiennym określeniem ich rodzaju. Zgodnie z art. 2 pkt 1 u.u.nazw. jednostka osadnicza to wyodrębniony przestrzennie obszar zabudowy mieszkaniowej wraz z obiektami infrastruktury technicznej zamieszkany przez ludzi. W świetle przytoczonych przepisów za miejscowość należy więc uznać wyodrębniony przestrzennie obszar zabudowy mieszkaniowej wraz z obiektami infrastruktury technicznej zamieszkany przez ludzi (tzw. jednostka osadnicza) lub inny obszar zabudowany, odróżniające się od innych miejscowości odrębną nazwą, a przy jednakowej nazwie - odmiennym określeniem ich rodzaju. Miejscowość może być uznana za zamieszkałą lub niezamieszkałą. Miejscowość zamieszkała jest to miejscowość, w której stale przebywa lub jest zameldowana na pobyt czasowy co najmniej jedna osoba (art. 2 pkt 6 u.u.nazw.). Miejscowość niezamieszkała jest to natomiast miejscowość, w której nie przebywa na stałe lub nie jest zameldowana na pobyt stały co najmniej jedna osoba (art. 2 pkt 5 u.u.nazw.). Ze względu na rodzaj miejscowości dzieli się na miasta ${ }^{7}$, osiedla $^{8}$, wsie $^{9}$, osady $^{10}$, kolonie ${ }^{11}$, przysiółki ${ }^{12}$ lub ich części (art. 2 pkt 11 u.u.nazw.).

Opłata miejscowa nie może być wprowadzona na terenie, który nie jest uznawany za miejscowość (nie leży w granicach jednostki osadniczej lub innego obszaru zabudowanego), co wynika a contario z art. 17 ust. 1 u.p.lok.

Obok miejscowości ustawa o urzędowych nazwach miejscowości wyróżnia tzw. obiekty fizjograficzne, definiowane jako wyodrębnione składniki środowiska

7 Zgodnie $z$ art. 2 pkt 3 u.u.nazw. za miasto uważa się jednostkę osadniczą o przewadze zwartej zabudowy i funkcjach nierolniczych posiadającą prawa miejskie bądź status miasta nadany w trybie określonym odrębnymi przepisami.

8 Zgodnie $\mathrm{z}$ art. 2 pkt 9 u.u.nazw. za osiedle uważa się zespół mieszkaniowy stanowiący integralną część miasta lub wsi.

9 Zgodnie z art. 2 pkt 12 u.u.nazw. za wieś uważa się jednostkę osadniczą o zwartej lub rozproszonej zabudowie i istniejących funkcjach rolniczych lub związanych z nimi usługowych lub turystycznych nieposiadającą praw miejskich lub statusu miasta.

10 Zgodnie $\mathrm{z}$ art. 2 pkt 8 u.u.nazw. za osadę uważa się niewielką jednostkę osadniczą na terenie wiejskim o odmiennym (wyróżniającym się) charakterze zabudowy albo zamieszkaną przez ludność związaną z określonym miejscem lub rodzajem pracy, w szczególności: osadę młyńską, osadę leśną, osadę rybacką, osadę kolejową, osadę po byłym państwowym gospodarstwie rolnym; osada może być samodzielna lub może stanowić część innej jednostki osadniczej.

11 Zgodnie z art. 2 pkt 2 u.u.nazw. za kolonię uważa się jednostkę osadniczą powstałą jako rezultat ekspansji miejscowości poza obszar wcześniej istniejącej zabudowy, w szczególności: kolonię miasta, kolonię wsi.

12 Zgodnie z art. 2 pkt 10 u.u.nazw. za przysiółek uważa się skupisko kilku gospodarstw położonych poza zabudową wsi stanowiące integralną część wsi. 
geograficznego, do których zalicza się w szczególności: nizinę, wyżynę, wzgórze, pasmo górskie, górę, szczyt góry, przełęcz, dolinę, kotlinę, jaskinię, rzekę, kanał, jezioro, zatokę, bagno, staw, sztuczny zbiornik wodny, wodospad, las, kompleks leśny, uroczysko, półwysep, wyspę (art. 2 pkt 7 u.u.nazw.).

Mając na względzie przytoczone definicje miejscowości oraz obiektu fizjograficznego, należy zauważyć, że tzw. binduga, definiowana w pytaniach jako miejsce nad rzeką, kanałem lub jeziorem ${ }^{13}$, zaliczana jest do obiektów fizjograficznych. Obiekt taki może być częścią miejscowości i wówczas - o ile spełnione są pozostałe warunki wynikające z ustawy o podatkach i opłatach lokalnych - od osób przebywających na jego terenie może być pobierana opłata miejscowa. Jeżeli natomiast obiekt taki (w tym przypadku binduga) znajduje się poza obszarem miejscowości (stanowi samodzielny obiekt fizjograficzny, niewłączony w obszar miejscowości), wówczas brak jest podstaw prawnych do wprowadzenia na terenie tego obiektu opłaty miejscowej.

- Warunki, jakie musi spełniać miejscowość, aby można było wprowadzić opłatę miejscową

Nie w każdej miejscowości może być wprowadzona opłata miejscowa, ale tylko w miejscowościach spełniających kryteria określone w art. 17 ust. 1 pkt 1 i 2 u.p.lok. Ustawodawca rozróżnia dwa rodzaje takich miejscowości.

Pierwszą grupę stanowią miejscowości posiadające korzystne właściwości klimatyczne, walory krajobrazowe oraz warunki umożliwiające pobyt osób w celach turystycznych, wypoczynkowych lub szkoleniowych. Co ważne, wszystkie te warunki powinny być spełnione łącznie. Nie można wprowadzić opłaty miejscowej w miejscowości, która co prawda posiada walory krajobrazowe i dysponuje warunkami umożliwiającymi pobyt osób w celach turystycznych, wypoczynkowych lub szkoleniowych, jednak nie spełnia kryterium korzystnych warunków klimatycznych ${ }^{14}$.

Minimalne warunki, jakie powinna spełniać miejscowość, w której można pobierać opłatę miejscową, określone zostały przez Radę Ministrów w rozporządzeniu z 18 grudnia 2007 r. w sprawie warunków, jakie powinna spełniać miejscowość, w której można pobierać opłatę miejscową, wydanym na podstawie upoważnienia ustawowego $\mathrm{z}$ art. 17 ust. 3 i 4 u.p.lok.

Minimalne warunki klimatyczne zostały określone w odniesieniu do poziomów substancji szkodliwych w powietrzu oraz poziomu pól elektromagnetycznych (\$2), minimalne warunki krajobrazowe w odniesieniu do elementów środowiska przyrodniczego istotnych dla wypoczynku lub walorów krajoznaw-

13 Por. również Słownik języka polskiego PWN, https://sjp.pl/binduga [dostęp 19 lutego 2019 r.].

14 Zob. np. wyrok NSA dotyczący opłaty miejscowej w Zakopanem z 15 marca 2018 r., sygn. akt II FSK 3579/17, LEX nr 2467865. 
czych $(\$ 3)$, zaś minimalne warunki pobytowe, umożliwiające pobyt w celach turystycznych, wypoczynkowych lub szkoleniowych w odniesieniu do bazy noclegowej w obiektach hotelarskich i innych obiektach, w których mogą być świadczone usługi hotelarskie w rozumieniu przepisów o usługach turystycznych $(\$ 4)$.

Zgodnie z art. 3 pkt 8 u.u.hot. za usługi hotelarskie uważa się krótkotrwałe, ogólnie dostępne wynajmowanie domów, mieszkań, pokoi, miejsc noclegowych, a także miejsc na ustawienie namiotów lub przyczep samochodowych oraz świadczenie, w obrębie obiektu, usług z tym związanych. Zgodnie $\mathrm{z}$ art. 35 ust. 1 i 2 u.u.hot. usługi hotelarskie mogą być świadczone:

- w obiektach hotelarskich, które spełniają: a) wymagania co do wielkości obiektu, jego wyposażenia oraz zakresu świadczonych usług, ustalone dla rodzaju i kategorii, do których obiekt został zaszeregowany, b) wymagania sanitarne, przeciwpożarowe oraz inne określone odrębnymi przepisami (ust. 1),

- w innych obiektach, jeżeli obiekty te spełniają minimalne wymagania co do wyposażenia ${ }^{15}$ oraz sanitarne, przeciwpożarowe oraz inne określone odrębnymi przepisami (ust. 2$)^{16}$.

Ustawa o usługach hotelarskich oraz usługach pilotów wycieczek i przewodników turystycznych wyróżnia osiem rodzajów obiektów turystycznych: hotele, motele, pensjonaty, kempingi (campingi), domy wycieczkowe, schroniska młodzieżowe, schroniska, pola biwakowe ${ }^{17}$ (art. 36 u.u.hot.).

15 Standard wyposażenia określa minister właściwy do spraw turystyki. Zob. rozporządzenie Ministra Gospodarki i Pracy z 19 sierpnia 2004 r. w sprawie obiektów hotelarskich, w których są świadczone usługi hotelarskie, t.j. Dz.U. 2017, poz. 2166.

16 Zgodnie z art. 35 ust. 3 u.u.hot. za inne obiekty, w których mogą być świadczone usługi hotelarskie, uważa się także wynajmowane przez rolników pokoje i miejsca na ustawianie namiotów w prowadzonych przez nich gospodarstwach rolnych, jeżeli obiekty te spełniają minimalne wymagania co do wyposażenia oraz sanitarne, przeciwpożarowe oraz inne określone odrębnymi przepisami.

17 Za hotele uważa się obiekty posiadające co najmniej 10 pokoi, w tym większość miejsc w pokojach jedno- i dwuosobowych, świadczące szeroki zakres usług związanych z pobytem klientów (art. 36 pkt 1 u.u.hot.).

Za motele uważa się obiekty położone przy drogach, dysponujące parkingiem, posiadające co najmniej 10 pokoi, w tym większość miejsc w pokojach jedno- i dwuosobowych (art. 36 pkt 2 u.u.hot.).

Za pensjonaty uważa się obiekty posiadające co najmniej 7 pokoi, świadczące dla swoich klientów całodzienne wyżywienie (art. 36 pkt 3 u.u.hot.).

Za kempingi (campingi) uważa się obiekty strzeżone, umożliwiające nocleg w namiotach, samochodach mieszkalnych (campobusach) i przyczepach samochodowych, przyrządzanie posiłków, parkowanie samochodów, a także świadczące usługi związane z pobytem klientów; obiekty te mogą dodatkowo umożliwiać nocleg w domkach turystycznych lub innych obiektach stałych (art. 36 pkt 4 u.u.hot.). 
Do obiektów tych nie zalicza się portów i przystani na wodach śródlądowych (rzekach, kanałach, jeziorach). Takie zdefiniowanie warunków pobytowych (warunków umożliwiających pobyt w miejscowości osób w celach turystycznych, wypoczynkowych lub szkoleniowych) rodzi poważne wątpliwości, czy opłata miejscowa - o ile została wprowadzona w miejscowości, w której znajduje się port - może być pobierana od osób cumujących statki żeglugi śródlądowej (w tym przypadku jachty) w porcie.

Regulacje prawne dotyczące portów i przystani śródlądowych są bardzo skąpe. Definicję portu i przystani śródlądowej zawiera art. 5 ust. 1 pkt 3 u.ż.ś., który za port lub przystań uznaje akwen i grunt oraz związaną z nimi infrastrukturę, znajdującą się w granicach portu lub przystani ${ }^{18}$. Obok definicji portu lub przystani ustawodawca podaje również definicję portu macierzystego, stanowiąc w art. 5 ust. 1 pkt 4 u.ż.ś., że jest to port, który armator wskazał jako miejsce stałego postoju statku. Definicje portu i przystani oraz portu macierzystego zostały sformułowane w ustawie o żegludze śródlądowej dla celów określenia kompetencji dyrektorów urzędów żeglugi śródlądowej (art. 9 ust. 2 u.ż.ś.), uprawnień kontrolnych pracowników urzędów żeglugi śródlądowej (art. 10 ust. 2 u.ż.ś.), kompetencji ministra właściwego do spraw żeglugi śródlądowej (art. 15 ust. 2 i 8 u.ż.ś.) oraz rejestru statków (art. 19-22 u.ż.ś.). Biorąc pod uwagę przeznaczenie statków żeglugi śródlądowej, wyróżnić można m.in. porty towarowe, pasażerskie, rybackie, turystyczne ${ }^{19}$.

Za domy wycieczkowe uważa się obiekty posiadające co najmniej 30 miejsc noclegowych, dostosowane do samoobsługi klientów oraz świadczące minimalny zakres usług związanych z pobytem klientów (art. 36 pkt 5 u.u.hot.).

Za schroniska młodzieżowe uważa się obiekty przeznaczone do indywidualnej i grupowej turystyki młodzieżowej, dostosowane do samoobsługi klientów (art. 36 pkt 6 u.u.hot.).

Za schroniska uważa się obiekty zlokalizowane poza obszarami zabudowanymi, przy szlakach turystycznych, świadczące minimalny zakres usług związanych z pobytem klientów (art. 36 pkt 7 u.u.hot.).

Za pole biwakowe uważa się obiekty niestrzeżone, umożliwiające nocleg w namiotach (art. 36 pkt 8 u.u.hot.).

18 Podobnie port i przystań definiowane są w ustawie z 20 grudnia 1996 r. o portach i przystaniach morskich, t.j. Dz.U. 2017, poz. 1933; art. 2 pkt 2.

19 Zgodnie z art. 5 ust. 1 pkt 1 u.ż.ś. statkiem dla celów tej ustawy jest urządzenie pływające o napędzie mechanicznym lub bez napędu mechanicznego, w tym również prom, wodolot i poduszkowiec, przeznaczone lub używane na śródlądowych drogach wodnych do: a) przewozu osób lub rzeczy, b) pchania lub holowania, c) inspekcji, nadzoru nad bezpieczeństwem ruchu żeglugowego lub szkolenia, d) ratowania życia lub mienia, e) połowu ryb, f) wykonywania prac technicznych, utrzymania szlaków żeglugowych lub eksploatacji złóż kruszyw, g) uprawiania sportu lub rekreacji, h) celów mieszkalnych, biurowych, gastronomicznych, hotelowych lub warsztatowych, a także jako przystanie pływające, doki lub zakłady kąpielowe. 
Słownik języka polskiego definiuje port jako obszar wodny wraz z przylegającym do niego pasem lądu, wyposażony w urządzenia zapewniające postój i obsługę statków, przeładunek towarów i obsługę pasażerów ${ }^{20}$.

Zarówno z definicji ustawowej, zawartej w ustawie o żegludze śródlądowej, jak i z definicji słownikowej wynika, że port jest przede wszystkim miejscem postoju (cumowania) statków, port śródlądowy - statków żeglugi śródlądowej. Nie jest natomiast miejscem przeznaczonym do przebywania osób w rozumieniu art. 17 ust. 1 u.p.lok. Nie stanowi bowiem obiektu zapewniającego warunki dla celów pobytu w miejscowości, w której wprowadzono opłatę miejscową, w rozumieniu art. 17 ust. 1 pkt 1 u.p.lok. i przepisów wydanych na podstawie art. 17 ust. 3 i 4 u.p.lok., odsyłających w tym zakresie do ustawy o usługach hotelarskich.

Dodatkowo należy zwrócić uwagę na treść art. 17 ust. 5 u.p.lok., zgodnie z którym rada gminy ustala miejscowości odpowiadające warunkom określonym w przepisach wydanych na podstawie art. 17 ust. 3 i 4 u.p.lok., w których pobiera się opłatę miejscową. Upoważnienie dla rady gminy powiązane zostało expressis verbis $\mathrm{z}$ regulacjami określającymi warunki wprowadzenia i poboru opłaty miejscowej. Jak wskazuje NSA w wyroku z 15 marca $2018 \mathrm{r}^{21}$ : sformułowanie "ustala miejscowości” nie oznacza pełnej swobody decyzyjnej organu stanowiacego j.s.t. [jednostek samorządu terytorialnego - dopisek J.K.] w tym zakresie; przeciwnie, przepis ten powierza gminie ograniczona władze dyskrecjonalna, nakładając jednocześnie na organ stanowiący gminy obowiazek uprzedniej weryfikacji, czy dana miejscowość faktycznie spetnia przesłanki określone w przepisach prawa powszechnie obowiazujacego, wydanych na podstawie art. 17 ust. 3 i 4 u.p.lok. Organy stanowiace j.s.t. - wydajac uchwałe, o której mowa w art. 17 ust 5 u.p.lok. - nie moga zatem działać woluntarystycznie, lecz winny stosować się do określonej $w$ ustawie procedury stanowienia przepisów prawa miejscowego w tym konkretnym przedmiocie; rada gminy, chcą wprowadzić opłate miejscowa, zobowiązana jest dokonać $w$ sposób transparentny wnikliwej i miarodajnej anali$z y$, czy warunki klimatyczne lub krajobrazowe [również pobytowe - dopisek J.K.] istniejące $w$ danej miejscowości odpowiadaja przesłankom określonym w rozporzadzeniu wydanym na podstawie art. 17 ust. 3 i 4 u.p.lok. Rozstrzygnięcie powyższej kwestii musi opierać się na stwierdzeniu określonych faktów w kontekście przesłanek określonych $w$ rozporzadzeniu RM; nie można traktować go wyłacznie jako „oświadczenie woli” rady gminy wprowadzenia $w$ danej miejscowości opłaty miejscowej. Uchwała, o której mowa w art. 17 ust. 5 u.p.lok. stanowi $w$ istocie wynik procesu weryfikacji przez organ stanowiacy gminy istnienia $w$ danej miejscowości warunków, od których spetnienia uzależnione jest powstanie kompetencji do wydania konkretnej normy statuujacej obowiazek uiszczenia opłaty miejscowej.

20 Słownik języka polskiego PWN, https://sjp.pl/port [dostęp 19 lutego 2019 r.].

${ }^{21}$ Sygn. akt II FSK 3579/17, LEX nr 2467865. Zob. też: http://orzeczenia.nsa.gov.pl/ doc/7CAFF8F61E [dostęp 19 lutego 2019 r.]. 
Tym samym należy - zdaniem autora - uznać, że nawet, jeżeli port śródlądowy (przystań) znajduje się w miejscowości, która jest objęta opłatą miejscową, od osób tam przebywających nie można pobierać takiej opłaty.

Co prawda, biorąc pod uwagę jedynie literalne brzmienie art. 17 ust. 1 u.p.lok., można byłoby wyprowadzić wniosek, że jeżeli miejscowość spełnia warunki wynikające z art. 17 ust. 1 pkt 1 u.p.lok. i przepisów wydanych na podstawie art. 17 ust. 3 i 4 u.p.lok. i rada gminy wprowadziła w tej miejscowości opłatę miejscową, to opłata ta pobierana może być od każdej osoby przebywającej w tej miejscowości, bez względu na to, czy korzysta ona, czy też nie korzysta z bazy noclegowej (pobytowej) w obiektach hotelarskich i innych obiektach, w których mogą być świadczone usługi hotelarskie w rozumieniu ustawy o usługach hotelarskich ( $\$ 4$ rozporządzenia Rady Ministrów z 18 grudnia 2007 r.). Interpretacja taka pomijałaby jednak warunki ustawowe wprowadzenia opłaty miejscowej, wynikające z art. 17 ust. 1 pkt 1 u.p.lok. Są nimi korzystne właściwości klimatyczne, walory krajobrazowe oraz warunki umożliwiające pobyt osób w celach turystycznych, wypoczynkowych lub szkoleniowych. Przy czym, jak już wcześniej wskazano, muszą one być spełnione łącznie. Korzystanie z właściwości klimatycznych oraz walorów krajobrazowych zostało połączone z możliwością skorzystania z bazy pobytowej (noclegowej). Tym samym ustawodawca przesądził, że pobyt w rozumieniu art. 17 ust. 1 pkt 1 u.p.lok. oznacza pobyt w danej miejscowości możliwy do zweryfikowania według obiektywnego kryterium. Jest nim skorzystanie przez turystę, wczasowicza, uczestnika szkolenia z bazy pobytowej (noclegowej) w rozumieniu $\$ 4$ rozporządzenia Rady Ministrów z 18 grudnia 2007 r. Każdy inny pobyt w miejscowości objętej opłatą miejscową jest pobytem nieweryfikowalnym pod względem jego długości (czasu, okresu) trwania, a tym samym brak jest możliwości poboru opłaty miejscowej zgodnie z przepisami ustawy o podatkach i opłatach lokalnych (po upływie doby od momentu przybycia do takiej miejscowości i za każdą rozpoczętą dobę pobytu). Przesłanka umożliwiająca wprowadzenie opłaty miejscowej w postaci istnienia warunków umożliwiających pobyt osób fizycznych w celach turystycznych, wypoczynkowych lub szkoleniowych na danym terenie ma charakter przesłanki koniecznej (sine qua non) nie tylko do ustanowienia (wprowadzenia) tej opłaty, ale i jej skutecznego poboru - określenia podatnika poprzez zweryfikowanie jego danych, czasu jego pobytu, a także zasad płatności opłaty, a więc obowiązków podatnika, terminów płatności oraz zasad poboru opłaty przez inkasentów.

Nałożenie ciężaru daninowego (podatkowego), w tym wypadku w zakresie opłaty miejscowej, nie może być działaniem oderwanym od możliwości wykonania tego obowiązku i kosztów poboru takiej daniny. Stąd ustawodawca postanowił, że jedną z przesłanek wprowadzenia opłaty miejscowej jest istnienie odpowiednich warunków pobytowych (umożliwiających pobyt osób w danej miejscowości w celach turystycznych, wypoczynkowych lub szkoleniowych). Definiując te warunki, normodawca odesłał do przepisów regulujących świad- 
czenie usług hotelarskich. Te zaś nie zaliczają portów i przystani śródlądowych do obiektów, w których mogą być świadczone usługi hotelarskie. Skoro normodawca nie wskazał portów i przystani śródlądowych jako obiektów zapewniających miejsce pobytu dla celów turystycznych, wypoczynkowych lub szkoleniowych, to nie można uznać, że od osób cumujących jachty w porcie można pobierać opłatę miejscową. Nie można bowiem w wiarygodny sposób zweryfikować przede wszystkim czasu przebywania poszczególnych członków załogi w porcie, co jest warunkiem niezbędnym ustalenia momentu powstania obowiązku podatkowego w opłacie miejscowej w stosunku do każdego z nich (opłata miejscowa jest świadczeniem indywidualnym) oraz wysokości należnej opłaty miejscowej (czas postoju jachtu w porcie nie musi się pokrywać $\mathrm{z}$ czasem przebywania poszczególnych członków załogi w porcie, co jest jedynym wiarygodnym elementem weryfikującym zakres obowiązku podatkowego poszczególnych członków załogi w zakresie opłaty miejscowej).

Drugą grupę miejscowości, w których można wprowadzić opłatę miejscową, stanowią miejscowości znajdujące się na obszarach, którym nadano status obszaru ochrony uzdrowiskowej na zasadach określonych w ustawie o lecznictwie uzdrowiskowym, uzdrowiskach i obszarach ochrony uzdrowiskowej oraz o gminach uzdrowiskowych. Zgodnie $\mathrm{z}$ art. 34 ust. 2 tej ustawy status obszaru ochrony uzdrowiskowej może być nadany obszarowi, który łącznie spełnia następujące warunki: a) posiada złoża naturalnych surowców leczniczych o potwierdzonych właściwościach leczniczych na zasadach określonych w ustawie, b) posiada klimat o właściwościach leczniczych potwierdzonych na zasadach określonych $\mathrm{w}$ ustawie, c) spełnia określone $\mathrm{w}$ przepisach o ochronie środowiska wymagania w stosunku do środowiska, d) posiada infrastrukturę techniczną w zakresie gospodarki wodno-ściekowej, energetycznej, w zakresie transportu zbiorowego, a także prowadzi gospodarkę odpadami.

Opłata miejscowa może być pobierana wyłącznie od osób przebywających w miejscowości, spełniającej warunki określone w art. 17 ust. 1 pkt 1 i 2 u.p.lok., dłużej niż dobę w celach turystycznych, wypoczynkowych lub szkoleniowych. $\mathrm{W}$ art. 17 ust. 1 u.p.lok. chodzi o przebywanie faktyczne, które nie musi być potwierdzone administracyjnie w trybie przepisów ustawy z 24 września $2010 \mathrm{r}$. o ewidencji ludności (t.j. Dz.U. 2018, poz. 1382, ze zm.) ${ }^{22}$. Fakt przebywania musi być jednak, jak zauważono wcześniej, możliwy do weryfikacji, co jest warunkiem niezbędnym skutecznego poboru opłaty miejscowej.

O ile zawinięcie do portu (przystani) śródlądowej związane jest przeważnie z pobytem żeglarzy na danym obszarze w celach turystycznych, wypoczynkowych lub szkoleniowych, o tyle spełnienie drugiego $\mathrm{z}$ warunków poboru opłaty miejscowej od żeglarza cumującego jacht w porcie lub przystani śródlądowej -

22 Zob. również pismo Ministerstwa Finansów, Departament Podatków Lokalnych i Katastru z 29 października 2001 r., nr LK-1302/LP/01/IP, „Biuletyn Skarbowy” 2002, nr 1. 
czas pobytu dłuższy niż dobę ${ }^{23} \mathrm{w}$ tym porcie - należy uznać za mało realny do spełnienia. A tylko w takim przypadku możliwe byłoby rozważenie ewentualnego poboru opłaty miejscowej.

Jeżeli jacht, a co za tym idzie jego załoga przebywaliby w porcie (przystani) krócej niż dobę, wówczas opłata miejscowa - o ile by obowiązywała w danej miejscowości i przy zastrzeżeniach podniesionych wcześniej - nie mogłaby być pobrana.

Niemniej należy zauważyć, że rady niektórych gmin podjęły uchwały nakładające na zarządy portów obowiązek poboru opłaty miejscowej od członków załóg jachtów (statków żeglugi śródlądowej) cumujących w portach śródlądowych ${ }^{24}$.

\section{- Obowiązki gminy w zakresie utrzymania czystości i porządku a opłata miejscowa}

Jako jeden $\mathrm{z}$ argumentów przemawiających za poborem opłaty miejscowej od żeglarzy cumujących jachty i inne statki żeglugi śródlądowej w portach, przystaniach, bindugach wskazano fakt, że podobnie jak inni turyści produkują oni śmieci, ścieki, zużywają prąd, wodę. W tym kontekście należy zauważyć, że:

- opłata miejscowa (podobnie jak uzdrowiskowa) jest daniną odpłatną w tym znaczeniu, że jej odpłatność związana jest - jak wskazuje się w literaturze przedmiotu $^{25}$ - z przebywaniem w miejscowościach o szczególnych walorach klimatycznych, krajobrazowych i pobytowych. Z obowiązkiem jej zapłaty przez osobę przebywającą w danej miejscowości w celach turystycznych, wypoczynkowych lub szkoleniowych nie wiąże się żadne wzajemne świadczenie ze strony gminy (podmiotu, na rzecz którego opłata ta jest pobierana). Ekwiwalentność opłaty związana jest z walorami klimatycznymi i krajobrazowymi konkretnej miejscowości,

- utrzymanie czystości i porządku w gminach należy - zgodnie z art. 3 ust. 1 u.porz. - do obowiązkowych zadań własnych gminy. Ustawa ta nakłada na właścicieli nieruchomości obowiązki w zakresie utrzymania czystości i porządku (art. 5 ust. 1 u.porz.), m.in. poprzez wyposażenie nieruchomości w pojemniki służące do zbierania odpadów komunalnych oraz utrzymy-

23 Zob. w tym zakresie m.in. wyrok NSA w Warszawie z 6 maja 2016 r., sygn. akt II FSK 930/15, LEX nr 2050884, http://orzeczenia.nsa.gov.pl/doc/2B17CE2104 [dostęp 19 lutego 2019 r.].

24 Zob. np. uchwałę XVI/129/2015 Rady Gminy Ruciane Nida z 14 grudnia 2015 r., http://bip.ruciane-nida.pl/prawo.php?wiad=1801 [dostęp 19 lutego 2019 r.]; uchwałę nr XVIII/10/2016 Rady Miejskiej w Giżycku z 27 stycznia 2016 r., https://bip-files. idcom-web.pl/sites/3080/wiadomosci/15745/files/uchwala_nr_xviii102016_rady_ miejskiej_w_gizycku_z_dnia27_stycznia_2016_r_w_sprawie_oplaty_miejscowej. pdf [dostęp 19 lutego 2019 r.].

25 Zob. B. Pahl, Podatki i opłaty lokalne. Teoria i praktyka, Wolters Kluwer, Warszawa 2017, s. 65. 
wanie tych pojemników w odpowiednim stanie sanitarnym, porządkowym i technicznym, przyłączenie nieruchomości do istniejącej sieci kanalizacyjnej lub, w przypadku gdy budowa sieci kanalizacyjnej jest technicznie lub ekonomicznie nieuzasadniona, wyposażenie nieruchomości w zbiornik bezodpływowy nieczystości ciekłych lub w przydomową oczyszczalnię ścieków bytowych. Gminy są zaś obowiązane do zorganizowania odbierania odpadów komunalnych od właścicieli nieruchomości, na których zamieszkują mieszkańcy (art. $6 \mathrm{c}$ ust. 1 u.porz.) ${ }^{26}$. Zgodnie z art. 6h u.porz. właściciele nieruchomości obowiązani są ponosić na rzecz gminy, na terenie której są położone nieruchomości, opłatę za gospodarowanie opłatami komunalnymi,

- porty żeglugi śródlądowej pobierają opłaty portowe, m.in. na pokrycie kosztów utrzymania portu w odpowiednim stanie ${ }^{27}$, podobnie jak zarządcy bindug, którzy pobierają opłaty za cumowanie i postój jachtu. Z tych opłat pokrywane są koszty utrzymania porządku i czystości na danym obszarze (port, przystań, binduga).

W żadnym więc wypadku nie można wiązać obowiązku zapłaty opłaty miejscowej z nałożonymi na gminę obowiązkami w zakresie utrzymania porządku i czystości, przynajmniej w odniesieniu do żeglarzy korzystających z portów, przystani oraz bindug oddanych w zarząd najemcy.

\section{Ad pytanie 2}

Zgodnie z art. 9 o.p., zawierającym definicję inkasenta, inkasentem może być osoba fizyczna, osoba prawna lub jednostka organizacyjna niemająca osobowości prawnej. Ustawodawca nie ogranicza przy tym kręgu podmiotów, które mogą być ustanowione inkasentami, poprzez wprowadzenie szczególnych warunków lub cech inkasenta. Inkasentem może być każda osoba prawna, fizyczna lub jednostka organizacyjna niemająca osobowości prawnej. Inkasentem może być również podmiot mający podpisaną z gminą umowę (kontrakt) na sprzątanie linii brzegowej jeziora, rzeki lub kanału. Pamiętać jednak należy, że opłata miejscowa może być pobierana tylko w przypadku spełnienia ustawowych przesłanek jej wprowadzenia i poboru.

Jak wynika z przeprowadzonej wcześniej analizy, jedną z trzech przesłanek wprowadzenia opłaty miejscowej - obok walorów klimatycznych i krajobrazowych - jest posiadanie przez miejscowość warunków umożliwiających pobyt osób fizycznych w tej miejscowości w celach turystycznych, wypoczynkowych

26 Zgodnie $\mathrm{z}$ art. 6c ust. 2 u.porz. rada gminy może, $\mathrm{w}$ drodze uchwały stanowiącej akt prawa miejscowego, postanowić o odbieraniu odpadów komunalnych od właścicieli nieruchomości, na których nie zamieszkują mieszkańcy, a powstają odpady komunalne.

27 Zob.np.: http://stranda.pl/cennik/,https://portsztynort.pl/port/oplaty-portowe, https:// marigo.pl/port-zhp-cennik/ [dostęp 19 lutego 2019 r.]. 
lub szkoleniowych, które zostały sprecyzowane w rozporządzeniu Rady Ministrów z 18 grudnia 2007 r. poprzez odesłanie do ustawy o usługach hotelarskich. Tym samym pobór opłaty miejscowej możliwy jest w drodze inkasa tylko od osób, których pobyt w danej miejscowości jest możliwy do zweryfikowania według obiektywnych kryteriów, a więc przebywających w danej miejscowości dłużej niż jedną dobę, w obiektach hotelarskich w rozumieniu art. 36 u.u.hot., tzn. hotelach, motelach, pensjonatach, kempingach, domach wycieczkowych, schroniskach młodzieżowych, schroniskach i polach biwakowych lub korzystających z pokoi gościnnych wynajmowanych przez rolników lub miejsc udostępnionych przez nich na ustawienie namiotów (art. 35 ust. 3 u.u.hot.).

Możliwe jest więc ustanowienie inkasenta do poboru opłaty miejscowej od osób przebywających na bindudze, o ile binduga ta jest jednocześnie polem biwakowym i położona jest na terenie miejscowości, w której rada gminy wprowadziła opłatę miejscową. Jeżeli jednak binduga ta jest wyłącznie obiektem fizjograficznym w rozumieniu art. 2 pkt 7 u.u.nazw., to opłata taka nie może być pobierana. Zastrzec również należy, że opłata miejscowa w sytuacji opisanej wyżej będzie mogła być pobierana wyłącznie od osób korzystających z bindugi jako pola biwakowego, nie zaś przystani śródlądowej, i tylko wówczas, gdy pobyt takiej osoby będzie dłuższy niż jedną dobę.

Reasumując poczynione ustalenia, należy stwierdzić, że:

- opłata miejscowa może zostać wprowadzona wyłącznie w miejscowościach spełniających kryteria określone w art. 17 ust. 1 u.p.lok. i w przepisach wydanych na podstawie art. 17 ust. 3 i 4 u.p.lok., a co za tym idzie nie może obejmować osób przebywających na terenie obiektów fizjograficznych (np. bindugi), jeżeli obiekt taki nie znajduje się w granicach miejscowości (na jej obszarze), w której wprowadzono opłatę miejscową,

- porty śródlądowe nie są zaliczane do obiektów hotelarskich oraz innych obiektów, w których mogą być świadczone usługi hotelarskie, a co za tym idzie nie wypełniają dyspozycji art. 17 ust. 1 pkt 1 u.p.lok. w zakresie istnienia warunków umożliwiających pobyt osób fizycznych w celach turystycznych, wypoczynkowych lub szkoleniowych w miejscowości, w której wprowadzono opłatę miejscową,

- opłata miejscowa nie jest świadczeniem odpłatnym związanym z ustawowym obowiązkiem gminy utrzymania czystości i porządku na terenie gminy,

- przebywanie osoby fizycznej w danej miejscowości oznacza nie tylko pobyt faktyczny tej osoby w tej miejscowości, ale również pobyt możliwy do zweryfikowania pod względem danych tej osoby oraz czasu jej przebywania na konkretnym terenie, co jest warunkiem niezbędnym ustalenia prawidłowej kwoty należnej opłaty miejscowej od takiej osoby i skutecznego jej poboru. Ustawodawca weryfikowalność taką wiąże, poprzez określenie przesłanek wprowadzenia opłaty miejscowej, z istnieniem warunków umożliwiających pobyt osób fizycznych w celach turystycznych, wypoczynkowych lub szko- 
leniowych w danej miejscowości, definiowanych przez odesłanie do ustawy o usługach hotelarskich oraz usługach pilotów wycieczek i przewodników turystycznych.

Mając na uwadze wskazane argumenty, należy uznać, że wprowadzenie obowiązku poboru opłaty miejscowej przez zarządców portów lub bindug od członków załóg statków śródlądowych (jachtów) tam cumujących nie znajduje, zdaniem autora opinii, wystarczającej podstawy prawnej w ustawie o podatkach i opłatach lokalnych.

Niemniej należy zauważyć, że rady niektórych gmin nałożyły na zarządców portów obowiązek poboru takiej opłaty.

\section{Podsumowanie}

- Z treści art. 17 ust. 1 pkt 1 i 2 ustawy o podatkach i opłatach lokalnych wynika a contrario, że opłata miejscowa nie może być wprowadzona na terenie całej gminy, ale wyłącznie w poszczególnych jej miejscowościach: bądź posiadających korzystne właściwości klimatyczne, walory krajobrazowe oraz warunki umożliwiające pobyt osób w celach turystycznych, wypoczynkowych lub szkoleniowych, bądź też znajdujących się na obszarach, którym nadano status obszaru ochrony uzdrowiskowej.

- Binduga, definiowana jako miejsce nad rzeką, kanałem lub jeziorem, zaliczana jest do obiektów fizjograficznych w rozumieniu ustawy o urzędowych nazwach miejscowości i obiektów fizjograficznych. Obiekt taki może być częścią miejscowości i wówczas - o ile spełnione są pozostałe warunki wynikające z ustawy o podatkach i opłatach lokalnych - od osób przebywających na jego terenie może być pobierana opłata miejscowa. Jeżeli natomiast obiekt taki znajduje się poza obszarem miejscowości, wówczas brak jest podstaw prawnych do wprowadzenia na terenie tego obiektu opłaty miejscowej.

- Porty śródlądowe i przystanie nie są zaliczane do obiektów hotelarskich oraz innych obiektów, w których mogą być świadczone usługi hotelarskie, a co za tym idzie nie wypełniają dyspozycji art. 17 ust. 1 pkt 1 u.p.lok. w zakresie istnienia warunków umożliwiających pobyt osób fizycznych w celach turystycznych, wypoczynkowych lub szkoleniowych w miejscowości, w której wprowadzono opłatę miejscową.

- Wprowadzając przesłankę ustanowienia opłaty miejscowej w postaci istnienia warunków umożliwiających pobyt osób fizycznych w celach turystycznych, wypoczynkowych lub szkoleniowych w danej miejscowości, ustawodawca przesądził jednocześnie, że przebywanie $\mathrm{w}$ rozumieniu art. 17 ust. 1 pkt 1 u.p.lok. oznacza pobyt $\mathrm{w}$ danej miejscowości możliwy do zweryfikowania według obiektywnego kryterium, którym jest skorzystanie przez turystę, wczasowicza, uczest- 
nika szkolenia z bazy pobytowej (noclegowej) w rozumieniu przepisów wydanych na podstawie art. 17 ust. 3 i 4 u.p.lok.

- Mając na uwadze argumenty wskazane w opinii, należy uznać, że wprowadzenie obowiązku poboru opłaty miejscowej przez zarządców portów lub bindug od członków załóg statków śródlądowych (jachtów) tam cumujących nie znajduje wystarczającej podstawy prawnej w ustawie o podatkach i opłatach lokalnych. - Ustawodawca nie ogranicza kręgu podmiotów, które mogą być ustanowione inkasentami, przez wprowadzenie szczególnych warunków lub cech inkasenta. Inkasentem może być każda osoba prawna, fizyczna lub jednostka organizacyjna niemająca osobowości prawnej, również podmiot mający podpisaną z gminą umowę (kontrakt) na sprzątanie linii brzegowej jeziora, rzeki lub kanału.

\section{Bibliografia}

Pahl B., Podatki i opłaty lokalne. Teoria i praktyka, Wolters Kluwer, Warszawa 2017. 